\title{
オンライン表面繊維配向計の開発
}

日本製紙株式会社 中央研究所 $\bigcirc$ 福岡和彦, 畑野昭夫*1, 阿部裕司, 竹内伸夫*2

\section{Development of On-line System for Measuring Fiber Orientation on Paper Surface}

\author{
Kazuhiko Fukuoka, Akio Hatano*1, Yuji Abe \\ and Nobuo Takeuchi*2 \\ Central Research Laboratory, ${ }^{* 1}$ Goutsu Mill, \\ ${ }^{* 2}$ Fushiki Mill, Nippon Paper Industries Co., Ltd.
}

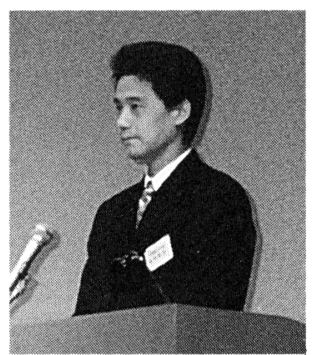

福岡和彦

It is known that fiber orientation is related to runnability of paper web, curling of paper, dimensional stability and so on. For producing paper with proper fiber orientation it is important to measure and control it in the papermaking process.

We developed the on-line sensor system to measure fiber orientation on paper surface and succeeded in measuring fiber orientation of paper running on paper machine.

\section{1.はじめに}

纎維配向は, 紙の力学的特性や寸法安定性を決定す る重要因子であり，カールなどの製品の走行性，作業 性に関する現象（紙ぐせ）に深く関与する。特に，情 報用紙等の抄造においては, 纎維配向の管理が最重要 項目の一つであり，この繊維配向をオンラインで計測 し制御することの意義は大きい。しかしながら, 現在 まで，繊維配向のオンライン計測が実用化されたとい う報告はない。

我々は, 既に, 紙表面の緎維配向測定法を開発して いるが1), さらに, 抄紙機上でこの表裏の繊維配向を 計測することができるオンライン表面繊維配向計を開 発した ${ }^{2)}$ 。現在, このシステムは, 実機抄紙機に設置 しており，品質管理に不可欠な計測機器として活用さ れている。本報告では, システムの概要と計測事例に ついて述べる。

${ }^{* 1}$ 江津工場, ${ }^{* 2}$ 伏木工場

\section{2. 測 定 原理}

紙面に対して，垂直に光を入射した場合，図 1 に示 したように，䋐維の側面による反射が存在する。入射 光軸を中心として試料を $360^{\circ}$ 回転させて得られた反 射光の強度分布は, 纎維配向性を反映したものであり, 次式により配向の強さを表す配向指数, 配向の方向を 表す配向角が算出される。

$$
\mathrm{F}(\theta)=\mathrm{C}\{1+\eta \operatorname{COS} 2(\theta-\alpha)\}
$$

ここで, $\mathrm{F}$; 反射光強度, $\mathrm{C}$; 反射光強度分布の平 均値, $\theta$; 試料の回転角度, $\eta$; 配向指数, $\alpha$; 配向角 である。

オンライン表面䋐維配向計は, 投光部および受光部 に可動部をもたない固定された光学配置を用いている。 紙面に対して偏光特性をもたない光（ランダム偏光） を垂直に入射し，紙面で反射した光強度分布を複数個 の受光部において同時に測定する (図 2)。この方法 により，光が照射された同一ヶ所において反射光の強 度分布が測定されるため, 抄紙工程中などの走行する 紙の繊維配向を正確に捕らえることができる。 


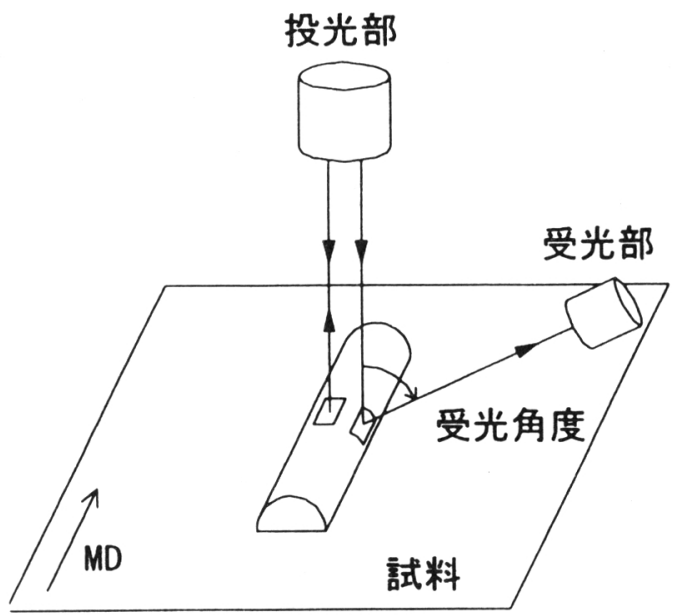

図 1 測定原理

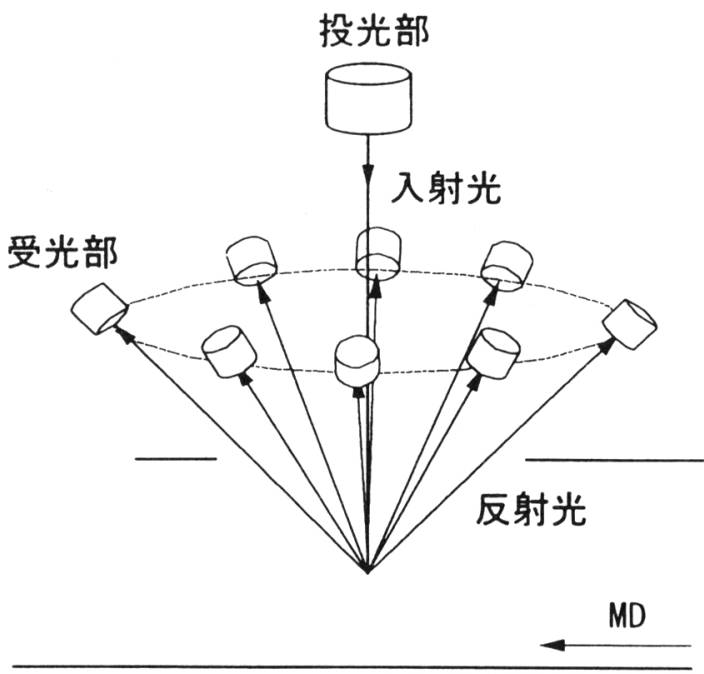

図 2 投受光部の光学配置

\section{3. オンライン纎維配向計システムの構成}

\section{1 センサーの構成}

センサーは，投受光部を配置した光学系と反射光の 強度信号を処理する電子回路系の 2 層の構造とした (写真 1)。投光部には, 半導体レーザー (出力 $30 \mathrm{~mW}$, 川偏光，入射スポット径 $10 \mathrm{~mm}$ ）を用いており，紙 面に対して光が垂直に入射するように配置している。 受光部では, 偏光子とシリコンフォトダイオード (SPD) を組み合わせており，受光角度 $50^{\circ}$ の位置で 10 組を等間隔に配置した。外形寸法は, $200 \times 200 \times$ $280 \mathrm{~mm}$ と小型化を実現することができた。

電子回路は, SPDで電気信号に变換された反射光

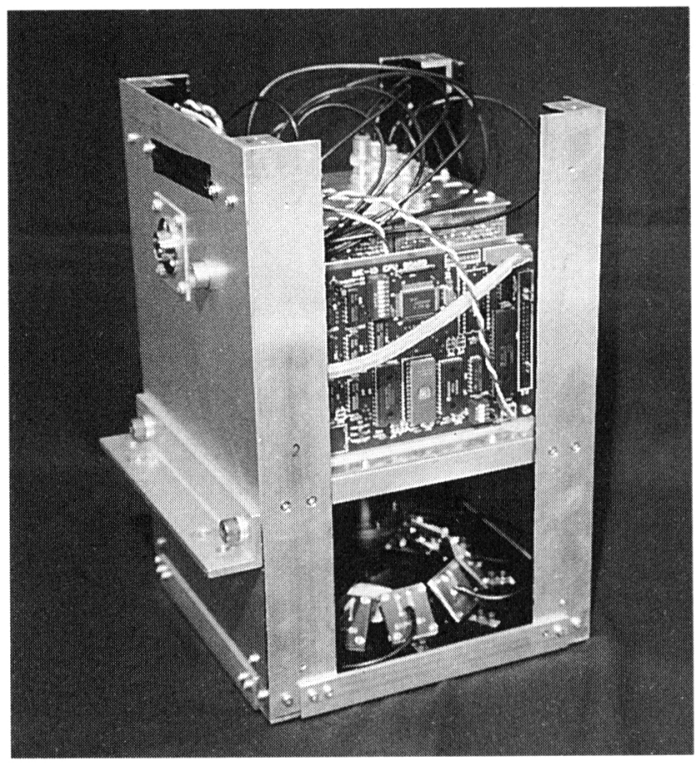

写真 1 センサー

強度を処理する増幅回路と $\mathrm{A} / \mathrm{D}$ 変換回路, これらの 処理を制御するCPUで構成した（図 3)。各回路は, 10 個のSPD にそれぞれ接続され, 同時に処理が行わ れる。そして，デジタル信号化した反射光強度は，一 時メモリに蓄積された後，システム制御装置に送信さ れる。

\section{2 システム構成とオンライン計測法}

オンライン表面繊維配向計システムは, 小松島工場 1 号マシンに設置した。F 面およびW 面センサーは, リールエンド直前の BM 計上部および下部へッドに

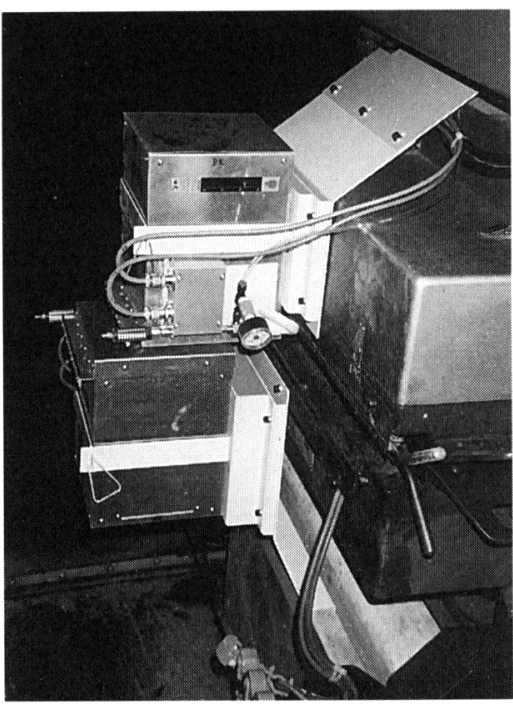

写真 2 BM 計に外付けしたセンサー 紙パ技協誌 第 53 巻第 3 号 


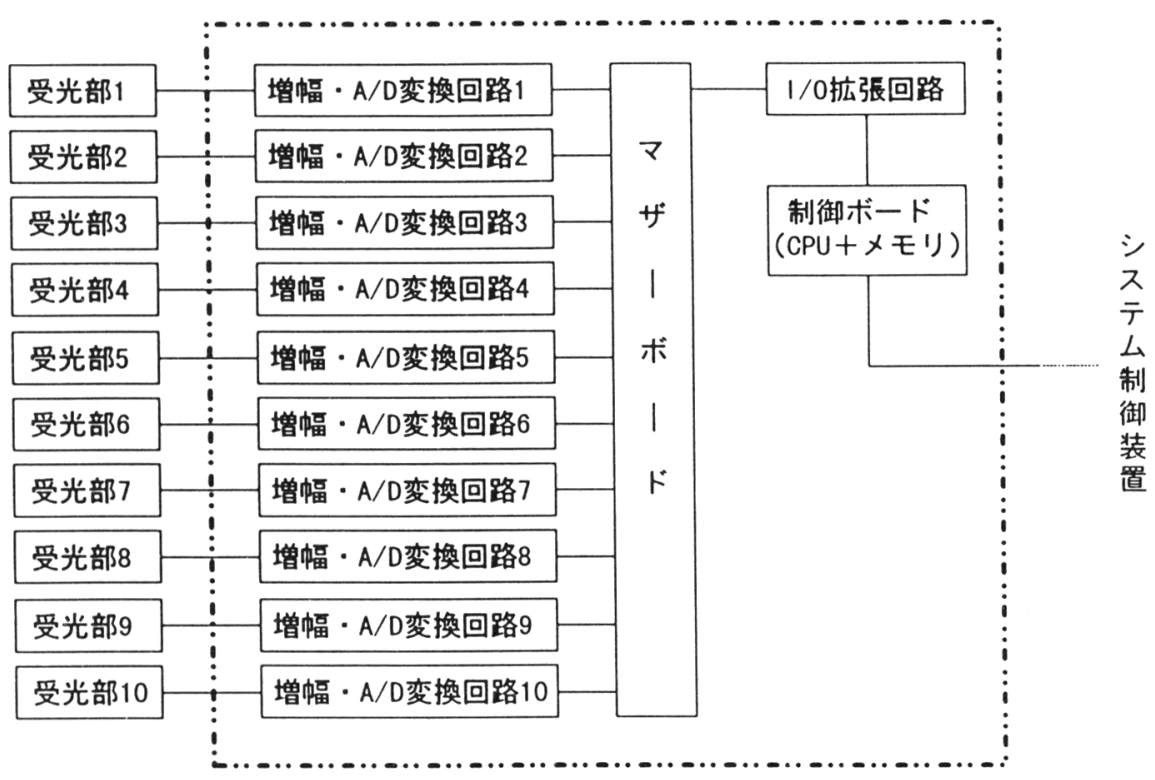

図 3 電子回路の概要

自製の治具により外付けし（写真 2)，センサーと紙 のパスラインの間隔は $9 \mathrm{~mm}$ とした。センサーは, 十 数メートルの通信ケーブルと電源ケーブルで中央操作 室に設置したシステム制御装置と接続されており，そ れらのケーブルは BM 計フレームと平行に特設した メッセンジャーワイヤー上を移動するようにした。

システム制御装置は, パソコン, ディスプレイ, ビ デオプリンタで構成した（写真 3)。パソコンでは, センサーから送信されてくる反射光強度分布から, 配 向指数および配向角を演算し，幅方向や流れ方向のプ ロファイルをディスプレイに表示する。したがって， 中央操作室で, 繊維配向をリアルタイムで監視するこ とができる。また，ディスプレイに表示される幅方向 や流れ方向のプロファイル (グラフ) 画面は, 必要に 応じてビデオプリンタに出力でき, 数值デー夕も, フ ロッピーディスクに記録することができる。

幅方向の走査方法は, 約 $3 \mathrm{~m}$ の紙幅に対して, ド ライブ側(DS) からテンダー側 (TS) へ走査を開始し, $\mathrm{F}$ 面七ンサーに内蔵した光電スイッチにより紙端を検 出後， $100 \mathrm{~mm}$ 間隔で合計 30 ヶ所（幅方向 No.1〜 30）において測定を行う（図4）。各測定ヶ所では, $500 \mu$ 秒間隔で 100 点測定し, その平均值がセンサー のメモリに一時保存される。センサーがTSから DS へ戻る間に，メモリに保存されていた幅方向 30 点分 の反射光の強度分布データが順にシステム制御装置に 送信され, 処理結果 (配向指数, 配向角) が表示され る。

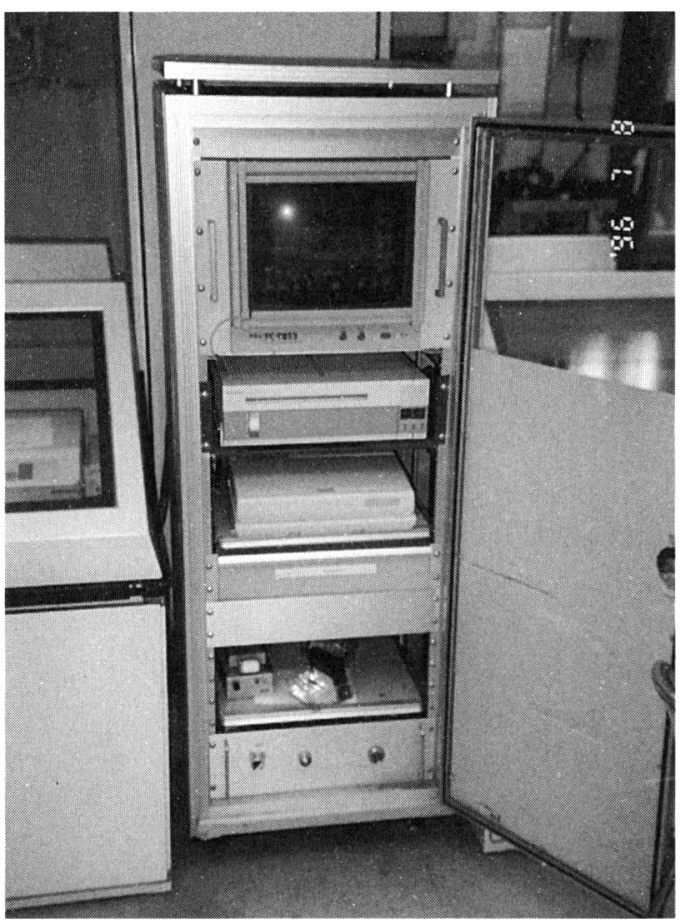

写真 3 システム制御装置

幅方向測定点数, 幅方向測定間隔, 測定回数, 測定 間隔は, システム制御装置のパソコンで設定し, 測定 条件としてセンサーCPUに送信される。したがって, 幅方向走査測定は, これらの条件に基づいてセンサー CPUの制御により行われる。 


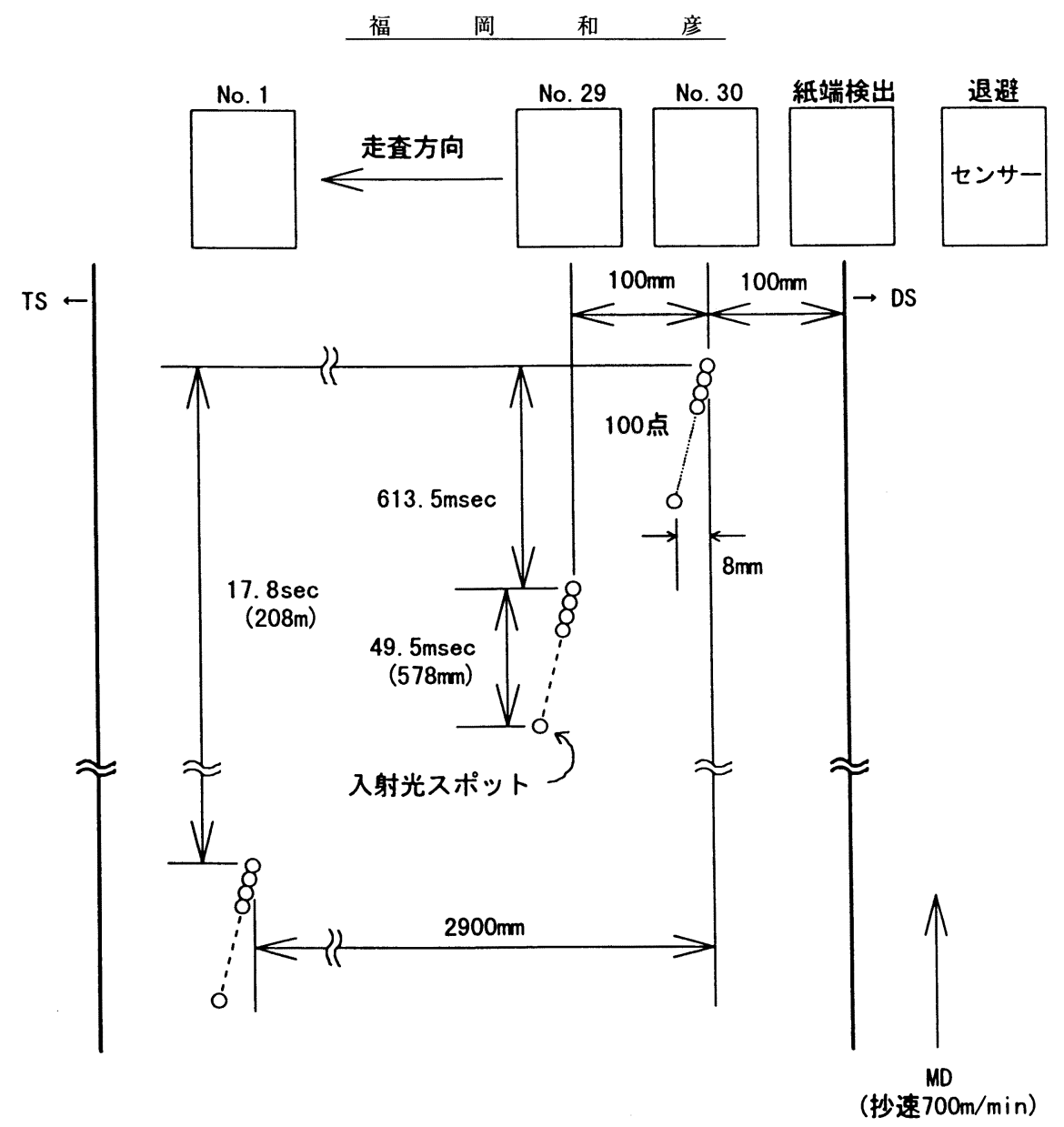

図 4 幅方向の走査方法

\section{4. オンライン計測結果}

\section{1 流れ方向の経時変化}

安定操業中に，オンライン測定を実施した結果を図 5 に示す。

配向指数および配向角は, フェルト面 (F 面), ワ イヤー面（W 面）ともに安定した数值を示しており， $\mathrm{F}$ 面は $\mathrm{W}$ 面と比較して若干変動が大きいが，これは， 長網式抄紙機では $\mathrm{F}$ 面が $\mathrm{W}$ 面より配向性がばらつき やすいことを表している。

また，13：40ごろ $\mathrm{F}$ 面の配向指数が上昇し，再び 元のレベルに戻るという变化が見られた。この時間に， 抄速が $670 \mathrm{~m} / \mathrm{minn}$ から $700 \mathrm{~m} / \mathrm{min}$ 一変更されてお り, 配向計は抄速の変更に伴った配向性の変動をオン ラインで捕らえたと言える。

\section{$4.2 \mathrm{~J} / \mathrm{W}$ 変更テスト}

$\mathrm{J} / \mathrm{W}$ 変更テスト $(99 \%$ 103\%) を実施し, 表裏䋐 維配向のオンライン測定を行った。
図6に示したように，J/W 変更に伴った配向性の 変化を連続的に捕らえていることがわかる。特に, $\mathrm{W}$ 面配向指数は, $\mathrm{J} / \mathrm{W}$ が $101 \%$ と $100 \%$ の間に最小 值が存在することを読み取ることができる。

\section{3 紙粉の影響}

抄紙工程中に発生する紙粉が，光学ウィンドウに付 着し, 入反射光を妨げる可能性がある。そこで, 紙粉 の付着状態の確認と配向測定値への影響について調査 した。

図 7 は，24 時間オンライン計測した配向角（全幅 方向の平均值）の経時変化を示したものである。 F 面 配向角は, $12: 00$ から 19 時間以上を経て， $-5.5^{\circ}$ か ら $0.5^{\circ}$ と $6^{\circ}$ ほど徐々に上昇した。 $12: 00$ に光学ウィ ンドウを確認したところ, 紙粉の付着は見られなかっ たが, 翌朝 8 時には, 光学ウィンドウ全面に紙粉が付 着していた。

紙粉は, 光学ウィンドウに徐々に付着するため, 受 光部で測定される反射光の強度分布に影響し, 配向角 

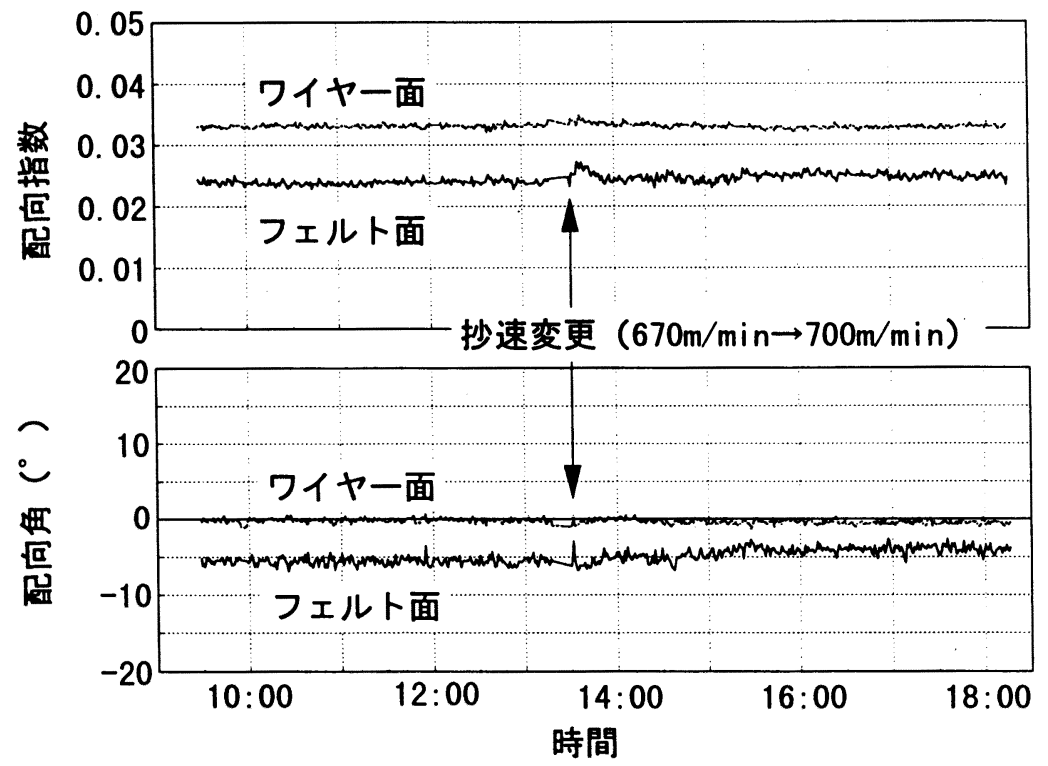

図 5 纎維配向性の経時变化（全幅方向平均）

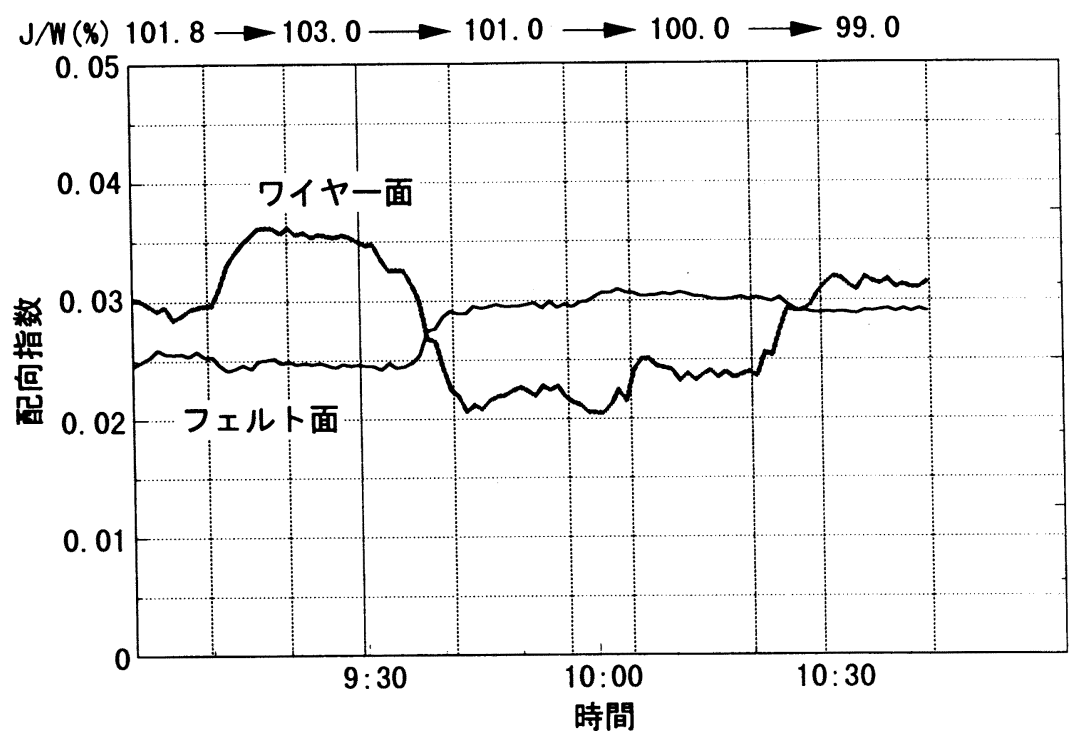

図 $6 \mathrm{~J} / \mathrm{W}$ 変更時の配向性の変化

の值が変化したものと思われる。この問題については, 光学ウィンドウをセンサーシャーシより若干突出させ て紙粉が付着しにくい構造としたこと,および，BM 計メンテナンスと並行して定期的な紙粉の拭き取り作 業を行うことにより, 紙粉の付着および配向測定值へ の影響が軽減され, 問題ないレベルに達していること を確認している。
5. ま と め

抄紙工程中の紙表面の繊維配向をリアルタイムで計 測可能なオンライン表面纎維配向計システムを開発し た。

本センサーは, 反射光の強度分布より, 紙表面の繊 維配向を計測するものであり, オンライン計測に適し た光学系を採用し, 投受光部および電子回路（信号処 


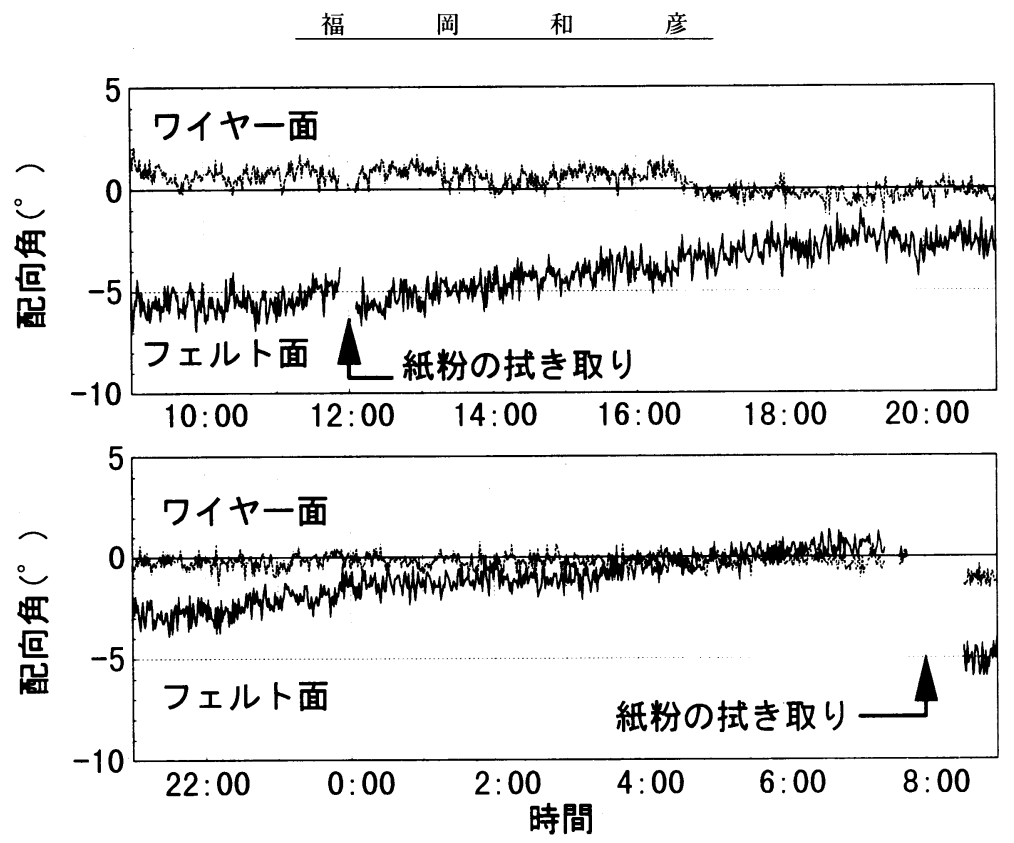

図 7 紙粉の影響

理回路）を内蔵している。センサーを BM 計上部お よび下部へッドに外付けして, 幅方向での走査測定が 可能なシステムを構筑し, 実機においてオンライン計 測を実施した結果，抄造条件の変更に伴った纎維配向 性の変化挙動をリアルタイムで捕らえることができた。 現在，このシステムは実機抄紙機に設置されており， 繊維配向のリアルタイム管理に活用されている。また, この技術を基本として, 横河電機と $\mathrm{BM}$ 計搭載型の オンライン表面繊維配向センサーの共同開発を進めて
きたが,このたび完成させることができた。この BM 計搭載型配向計は当社 2 工場に導入済みであり, 順調 に稼働していることを報告してまとめとする。

\section{参考文献 :}

（1）阿部裕司, 轟英伸, 竹内伸夫, 坂本祥: 紙パルプ 技術協会誌 第 49 巻(5)，849-860（1995）

（2）福岡和彦, 畑野昭夫, 阿部裕司, 竹内伸夫 : 第 63 回紙パルプ研究発表会 講演要旨集, 66-69 (1996) 